\title{
Metallo-stannosilicate heterogeneous catalyst for biodiesel production using edible, non-edible and waste oils as feedstock
}

\author{
Danilo Antonio da Silva ${ }^{\mathrm{a}}$, Oscar A.N. Santisteban ${ }^{\mathrm{a}}$, Adriano de Vasconcellos ${ }^{\mathrm{a}}$, Alex Silva Paula ${ }^{\mathrm{a}}$, \\ Donato A.G. Aranda ${ }^{\mathrm{b}}$, Marcus Vinicius Giotto $^{\mathrm{c}}$, Christian Jaeger ${ }^{\mathrm{d}}$, José G. Nery ${ }^{\mathrm{a}, *}$ \\ a Department of Physics, Institute of Biosciences, Letters and Exact Sciences, UNESP - São Paulo State University, Campus of São José do Rio Preto, São Paulo, 15054-000, \\ Brazil \\ ${ }^{\mathrm{b}}$ Greentec Laboratory, School of Chemistry, Federal University of Rio de Janeiro, RJ, 21941-972, Brazil \\ ${ }^{\mathrm{c}}$ Institute of Materials Science, University of Connecticut, 97 North Eagleville Road, Storrs, CT, 06269-3136, USA \\ d BAM Federal Institute for Materials Research and Testing, Division 1.3, Richard Willstaetter Strasse 11, D-12489, Berlin, Germany
}

\section{A R T I C L E I N F O}

\section{Keywords:}

Sol-gel chemistry

Metallo-stannosilicate

Biofuels

Biomass

Edible and non-edible lipid feedstocks

\begin{abstract}
A B S T R A C T
This study reports the synthesis, physicochemical characterization by X-ray powder diffraction (XRD), scanning electron microscopy (SEM) and solid-state MAS NMR $\left({ }^{1} \mathrm{H},{ }^{23} \mathrm{Na},{ }^{29} \mathrm{Si}\right.$ and ${ }^{119} \mathrm{Sn}$ MAS NMR) of a metallo-stannosilicate and its application as a heterogeneous catalyst for biodiesel production via ethanolysis and methanolysis routes using edible, non-edible an waste oils as feedstocks. XRD characterization of the metallo-stannosilicate has revealed a typical structure of mixed octahedral-pentahedral-tetrahedral material with an orthorhombic unit cell $\left(\mathrm{a}=14.522 \AA\right.$ Á, $\mathrm{b}=12.469 \AA$ Á, and $\mathrm{c}=10.654 \AA$ Á). ${ }^{119} \mathrm{Sn}$ single-pulse MAS NMR results presented two resonance lines, at $\delta_{1}=-683.8 \mathrm{ppm}$ and $\delta_{2}=-690.9 \mathrm{ppm}$, which were assigned to the tin octahedrally coordinated in the metallo-stannosilicate structure. Heterogenous catalytic studies in the transesterification of refined edible, non-edible, and waste oils have resulted in high yields of FAMEs and FAEEs (fatty acid methyl and ethyl esters), nevertheless the highest FAMES (98.2\%) and FAEEs (96.6\%) yields were obtained for non-edible microalgae oil extracted from the genetically modified heterotrophic algal strain Prototheca moriformis. Catalytic studies also using non-edible macaw palm oil (Acrocomia aculeata) with a high content of free fatty acids (FFAs) demonstrated that the catalyst could simultaneously perform esterification and transesterification reactions. These findings indicate the potential application of this novel metallo-stannosilicate in the production of renewable and environmentally clean biofuels, like biodiesel, using different sources of lipids feedstocks, notably those that do not compete with food production.
\end{abstract}

\section{Introduction}

The search for alternative fuels has stimulated and intensified the efforts of the scientific community to identify viable ways of producing biofuels to replace or reduce the use of fossil fuels. Among the ecofriendly green technology, biodiesel is an attractive option. It is a sustainable and renewable form of energy, less harmful to the environment in comparison to petroleum diesel [1]. Chemically, biodiesel consists of a mixture of fatty acid alkyl esters (FAAEs), and at the industrial scale, it is predominantly produced using transesterification reactions using refined vegetable oils as sources of triacylglycerides, together with short-chain alcohols (methanol or ethanol) and homogeneous catalysts. There are clear potential environmental benefits of replacing petroleum diesel with biodiesel. Nevertheless, there are several drawbacks associated with the choice of the triacylglyceride feedstocks and the catalysts that preclude a faster development of this industry.

Concerning the available triacylglyceride sources, the current use of edible vegetable oils as lipid feedstocks for biodiesel production, instead of their exclusive use as foods, has raised ethical and economic questions, and this controversy has been the main driving force behind scientific efforts to identify alternative triacylglyceride sources that do not compete with food production [2,3]. Regarding catalyst technology, homogeneous catalysts such as sodium hydroxide $(\mathrm{NaOH})$, potassium hydroxide $(\mathrm{KOH})$ and sodium methoxide $\left(\mathrm{NaOCH}_{3}\right)$ are currently the main catalysts agents employed in the biodiesel industry. Their advantages include high biodiesel yields under mild conditions and in relatively short reaction time [4]. Nevertheless, homogeneous catalysts also have drawbacks: (a) Due to its hygroscopic nature, homogeneous

\footnotetext{
* Corresponding author at: Rua Cristóvão Colombo 2265, São José do Rio Preto, SP, 15054-000, Brazil.

E-mail address: geraldo.nery@unesp.br (J.G. Nery).
} 
catalyst $(\mathrm{NaOH}, \mathrm{KOH})$ can be very hazardous for the environment, as compared to heterogeneous catalyst, (b) low quality feedstock vegetable oils with high contents of water and free fatty acids (FFAs) lead to the formation of soap, consequent loss of oil and problems of product separation during homogeneous catalytic transesterification. During homogeneous catalytic transesterification, the glycerol produced is of low quality and requires lengthy process and distillation for purification. All these processing increases the cost of the end products (biodiesel and glycerin). Moreover, the homogeneous base catalyzed transesterification process encountered problems to handle multiple feedstocks [5-7]. Therefore, from an economic, ethical, and environmental perspective, it is important to advance the development of more efficient catalysts that can be safely employed in industrial transesterification reactions using low-quality triacylglyceride feedstocks [8].

Although not currently predominantly employed on an industrial scale for biodiesel production using the transesterification process, heterogeneous catalysts could, in principle, be attractive alternatives to the homogeneous catalysts, since they are less sensitive to triacylglyceride feedstocks with high contents of FFAs and water [4,9]. Some of the advantages of the heterogeneous catalytic transesterification are: (a) the catalyst can be recycled (reused), (b) there is no or very less amount of wastewater produced during the process and (c) separation of the catalysts from biodiesel and glycerol is relatively easy, because the methanol or ethanol does not mix with the heterogeneous catalysts after the transesterification reaction [5]. There are several reports in the literature showing heterogeneous catalytic transesterification as a viable catalytic alternative for industrial large scale of biodiesel using batch or continuous processes $[8,10]$. Several excellent reviews have described a plethora of inorganic, organic and composite materials employed as heterogeneous catalysts in laboratory scale for biodiesel production: alkali metal oxides $(\mathrm{MgO}, \mathrm{CaO}, \mathrm{SrO}, \mathrm{BaO})$, transition metal oxides and their derivatives $\left(\mathrm{TiO}_{2} / \mathrm{SO}_{4}{ }^{2-}, \mathrm{ZrO}_{2} / \mathrm{SO}_{4}{ }^{2}\right.$ and $\left.\mathrm{Na}_{2} \mathrm{MoO}_{4}\right)$, mixed oxides and their derivatives (KF/Zn(Al)O, $\mathrm{Zn}(\mathrm{Al}) \mathrm{O}, \mathrm{KF} / \mathrm{Zn}(\mathrm{Al}) \mathrm{O}$, $\mathrm{MgO}-\mathrm{MgAl}_{2} \mathrm{O}_{4}, \mathrm{KNO}_{3} / \mathrm{ZrO}_{2}$ and $\mathrm{SO}_{4}{ }^{2-} / \mathrm{SnO}_{2}$ ), ion exchange resins type acid heterogeneous catalyst, carbon-based heterogeneous catalysts, boron group base heterogeneous catalyst, waste material based heterogeneous catalysts and enzyme-based heterogeneous catalyst [4,9,11-15]. Although microporous crystalline solid materials, built up of tetrahedrally coordinated (e.g., $\mathrm{Si}, \mathrm{Al}, \mathrm{P}$ ) atoms have been studied as heterogeneous catalysts for transesterification reactions, heterogeneous catalysts based on mixed octahedral-pentahedral-tetrahedral microporous (OPT) siliceous frameworks have not yet been reported in the literature for this purpose.

Chukanov et al. [16] and Rocha et al. [17] have reviewed the steady progress in methods of synthesis and investigation of physical properties and crystal-chemical features of silicate microporous materials with transition elements (so-called zeolite-like amphoterosilicates). Comprehensive research into synthetic OPT materials was initiated by the seminal contributions of the titanosilicates ETS-10 and ETS-4 [18], tantalo and niobiosilicates [19,20] and stannosilicates [21,22]. Materials of this type are promising ion exchangers, sorbents, catalysts or catalyst carriers and, accordingly, can be used in chromatography, catalysis, water purification, among another process. Unlike common zeolites being aluminosilicates, frameworks of amphoterosilicates with transition metals are built of both tetrahedral fragments and "strong" cations ( $\mathrm{Ti}, \mathrm{Nb}, \mathrm{Zr}, \mathrm{Ta}, \mathrm{Sn}, \mathrm{W}, \mathrm{Fe}, \mathrm{Mn}, \mathrm{Zn}$, etc) with coordination numbers 5 or 6 .

Tin-based homogeneous and heterogeneous catalyst have been used in triacylglyceride transesterification, mainly with refined edible oils as feedstocks and methanol as a solvent in the reaction, typically providing high yields of fatty acid methyl esters (FAMEs) [23-30]. Nevertheless, a careful analysis of the literature reveals a lack of technical information concerning the application of OPT tin-based catalysts for biodiesel production using edible, non-edible vegetable oils or various waste cooking and degummed oils as triacylglyceride feedstocks. Therefore, in order to address this gap, the present work describes the synthesis and the spectroscopic characterization of an OPT tin-based heterogeneous catalyst which was tested in the transesterification reaction of different sources of edible oils (soybean, corn, canola, sunflower), non-edible oils (microalgae, palm, macaw palm) and also waste cooking oils as lipid feedstocks. Both the methanolysis and ethanolysis routes were employed. Optimization of the transesterification reactions by taking into consideration relevant factors such as temperature, pressure, and the turnover (reuse) of the catalyst were also performed. The experimental herein reported indicate the potential of this OPT metallo-stannosilicate being employed as a viable heterogeneous catalyst for the production of biodiesel using both methanolysis and ethanolysis route and a variety of different kinds of lipid feedstocks, notably those that do not compete with food production.

\section{Materials and methods}

\subsection{Chemicals}

The stannosilicate synthesis and the catalytic reactions employed the following chemicals: Ludox HS-40 colloidal silica ( 40 wt. $\% \mathrm{SiO}_{2}$ in water), tin chloride dihydrate $\left(\mathrm{SnCl}_{2} \cdot 2 \mathrm{H}_{2} \mathrm{O}, 98 \%\right)$, and sodium hydroxide $(\mathrm{NaOH})$ were purchased from Sigma-Aldrich (Steinheim, Germany). Anhydrous methyl and ethyl alcohols (99.8\%) were purchased from Dinâmica Química (Diadema, Brazil). Refined and degummed palm oils (Elaeis guineensis) were obtained from Agropalma (Belém, Brazil). Refined soybean oil (Glycine max), corn oil (Zea mays), rapeseed oil (Brassica napus), sunflower oil (Helianthus annuus), and degummed soybean oil were acquired from Cargill (Sao Paulo, Brazil). Refined microalgae oil extracted from the genetically modified heterotrophic algal strain Prototheca moriformis and produced according to Trimbur et al. [31] was obtained from Solazyme Company (Orindiúva, Brazil). Degummed macaw palm oil (Acrocomia aculeata) was acquired from UBCM Company (Montes Claros, Brazil). The FFAs contents (wt. $\%$ ) and acid values (mg $\mathrm{KOH} \mathrm{g^{-1 }}$ ) were measured for all the lipid feedstocks used in this study, according to the AOCS Ca 5a-40 (2009).

\subsection{Hydrothermal synthesis of the stannosilicate}

The stannosilicate was synthesized using experimental procedures adapted from the literature [21,22]. In a typical synthesis, $21.1 \mathrm{~g}$ of sodium hydroxide $(\mathrm{NaOH})$ was dissolved in $15 \mathrm{~mL}$ of distilled water (solution A). In the next step, $54.9 \mathrm{~g}$ of Ludox HS-40 colloidal silica (40 wt. $\% \mathrm{SiO}_{2}$ in water) was added to solution $\mathrm{A}$ and the reaction mixture was kept under stirring for $30 \mathrm{~min}(500 \mathrm{rpm})$ at $25^{\circ} \mathrm{C}$, resulting in the formation of a homogeneous gel (solution B). Subsequently, $12.8 \mathrm{~g}$ of stannous chloride $\left(\mathrm{SnCl}_{2} \cdot 2 \mathrm{H}_{2} \mathrm{O}\right)$ was added to solution $\mathrm{B}$, under moderate stirring $(500 \mathrm{rpm})$ for $60 \mathrm{~min}$ at $25^{\circ} \mathrm{C}$, resulting in a homogeneous gel. The final sol-gel solution was transferred to a $125 \mathrm{~mL}$ Teflon-lined stainless steel autoclave (Parr Instruments Co., Illinois, USA) and kept at $200{ }^{\circ} \mathrm{C}$ from 2 days to 42 days. Afterward, the reactor was cooled down and the solid product was collected by filtration, washed with distilled water, and dried at $100{ }^{\circ} \mathrm{C}$ for $12 \mathrm{~h}$, prior to its physicochemical characterization and application in the catalytic reactions.

\subsection{Physicochemical characterization of the stannosilicate}

The as-synthesized stannosilicate was characterized by X-ray diffraction (XRD) using a Miniflex instrument (Rigaku, Tokyo, Japan) operated at $40 \mathrm{kV}, 15 \mathrm{~mA}$, with $\mathrm{Ni}$-filtered $\mathrm{Cu}-\mathrm{K} \alpha$ radiation $(\lambda=1.5418$ $\AA$ ), in the $2 \theta$ range from 3 to $80^{\circ}$, at a goniometer scan rate of $2^{\circ}(2 \theta)$ $\mathrm{min}^{-1}$. Scanning electron microscope (SEM) and energy-dispersive Xray spectrometry (EDS) analyses were performed using an Inspect F50 microscope (FEI Instruments, Oregon, USA) using the facilities of the Brazilian National Laboratory of Nanotechnology (LNNano, Electron 
Microscopy Laboratory, Campinas, Brazil). The electron microscope was equipped with a Schottky field emission source, the probe current was $200 \mathrm{~mA}$, and the electron beam acceleration voltage ranged between 0.2 and $30 \mathrm{kV}$. Atomic force microscope analyzes (AFM) were also made in the Brazilian National Laboratory of Nanotechnology (LNNano, Laboratory of Surface Science, Campinas, Brazil) using a Park NX-10 microscope (Park Systems, Santa Clara, USA) with scanning of $100 \mu \mathrm{m} \times 100 \mu \mathrm{m}$ and z-axis detector with amplitude of $15 \mu \mathrm{m}$, fitted with a PPP-NCHR probe operated at $320 \mathrm{KHz}$ resonance frequency and constant force of $42 \mathrm{~N} / \mathrm{m}$. Surface area measurements at $77 \mathrm{~K}$ were performed on a Micromeritics ASAP 2020 (Micrometrics Instrument Corporation, Norcross, USA) using the facilities of the BAM, Federal Institute for Materials Research and Testing (Division 1.3. Structural Analysis, Berlin, Germany). Before the measurement, all samples were degassed at temperature of $300^{\circ} \mathrm{C}$ and pressure of $5 \times 10^{-5} \mathrm{mbar}$ for $3 \mathrm{~h}$, and isotherms were processed by the BET (Brunauer-EmmettTeller) method.

Solid state magic angle spinning NMR (MAS NMR) experiments were performed using the facilities of the BAM, Federal Institute for Materials Research and Testing (Division 1.3, Structural Analysis, Berlin, Germany). The stannosilicate was characterized by ${ }^{1} \mathrm{H},{ }^{23} \mathrm{Na}$, ${ }^{29} \mathrm{Si}$, and ${ }^{119} \mathrm{Sn}$ solid-state MAS NMR. All the experiments were carried out at room temperature, with the samples filled into zirconia rotors equipped with Kel-F caps (Bruker, Wissembourg, France). The ${ }^{1} \mathrm{H}$ and ${ }^{23} \mathrm{Na}$ MAS NMR experiments were performed using a $600 \mathrm{MHz}$ Avance spectrometer (Bruker, Wissembourg, France) with $\mathrm{B}_{0}$ of $14.1 \mathrm{~T}$, using $4 \mathrm{~mm}\left({ }^{1} \mathrm{H}\right.$ nucleus $)$ and $2.5 \mathrm{~mm}\left({ }^{23} \mathrm{Na}\right.$ nucleus) MAS probes. The ${ }^{29} \mathrm{Si}$ and ${ }^{119} \mathrm{Sn}$ single-pulse MAS NMR experiments were performed using a Bruker $400 \mathrm{MHz}$ spectrometer $\left(\mathrm{B}_{0}=9.4 \mathrm{~T}\right)$ with $7 \mathrm{~mm}$ MAS probes. The data were analyzed and processed using the TopSpin 3.0 software. For removing the ${ }^{1} \mathrm{H}$ background signals of the MAS probe, the EASY method was employed [32,33] using a MAS frequency of $12.5 \mathrm{kHz}, 90^{\circ}$ pulse duration of $3 \mu \mathrm{s}$, recycle delay of $10 \mathrm{~s}$, and accumulation of 16 scans. For removing all ${ }^{1} \mathrm{H}$ backgrounds, an additional ${ }^{1} \mathrm{H}$ EASY spectrum of an empty rotor is needed, which is subtracted from the ${ }^{1} \mathrm{H}$ EASY spectrum of the sample. The ${ }^{1} \mathrm{H}$ chemical shifts were referenced to TMS, using adamantane as a secondary reference $(\delta=1.78 \mathrm{ppm})$.

The ${ }^{23} \mathrm{Na}$ single-pulse MAS NMR spectrum was obtained using radiofrequency pulses at a Larmor frequency of $158.7 \mathrm{MHz}$, MAS frequency of $25 \mathrm{kHz}, 90^{\circ}$ pulse duration of $3.4 \mu \mathrm{s}$, recycle delay of $10 \mathrm{~s}, 64$ scans, 2048 data points, and spectral width of $50 \mathrm{kHz}$. The ${ }^{23} \mathrm{Na}$ chemical shifts were reported relative to $\mathrm{NaCl}$ as a secondary reference $(\delta=7.3 \mathrm{ppm})$. The ${ }^{29} \mathrm{Si}$ single-pulse MAS NMR spectra were obtained using radiofrequency pulses at a Larmor frequency of $79.5 \mathrm{MHz}$, MAS frequency of $6.5 \mathrm{kHz}, 90^{\circ}$ pulse duration of $7.7 \mu \mathrm{s}$, and recycle delay varying from $2 \mathrm{~s}$ to $900 \mathrm{~s}$. The ${ }^{29} \mathrm{Si}$ chemical shifts were reported relative to kaolin as a secondary reference $(\delta=-91.5 \mathrm{ppm})$. The ${ }^{119} \mathrm{Sn}$ single-pulse MAS NMR spectra were obtained using radiofrequency pulses at a Larmor frequency of $149.1 \mathrm{MHz}$, MAS frequency of $6.5 \mathrm{kHz}$, $90^{\circ}$ pulse duration of $3.0 \mu \mathrm{s}$, and recycle delay varying from $2 \mathrm{~s}$ to $900 \mathrm{~s}$. The ${ }^{119} \mathrm{Sn}$ chemical shifts were reported relative to $\mathrm{SnO}_{2}$ as a secondary reference $(\delta=-604 \mathrm{ppm})$ [34].

\subsection{Transesterification reactions of the refined edible, non-edible, and waste oils}

Syntheses of FAMEs and FAEEs using the transesterification reactions were performed using the refined soybean oil (FFAs content $=$ 0.2 wt. $\%$, acid value $=0.4 \mathrm{mg} \mathrm{KOH} \mathrm{g}^{-1}$ ), palm oil (FFAs content $=$ 0.3 wt. $\%$, acid value $=0.6 \mathrm{mg} \mathrm{KOH} \mathrm{g}^{-1}$ ), corn oil, canola oil, sunflower oil, and microalgae oil (these last four triacylglyceride feedstocks presented FFAs contents $<0.1 \mathrm{wt} . \%$ and acid values $<0.2 \mathrm{mg}$ $\mathrm{g}^{-1}$ ), employing both the methanolysis and ethanolysis routes. A typical transesterification reaction, as exemplified for refined soybean oil as feedstock, was performed by transferring $20.0 \mathrm{~g}$ of the oil to a $100 \mathrm{~mL}$ open glass reactor equipped with a reflux condenser and a magnetic stirrer, immersed in a thermostatic bath. Anhydrous methanol or ethanol was added to give alcohol: oil molar ratio of 1:30. The appropriate amount of catalyst ( $3 \%$, relative to the mass of oil) was added and the reaction mixture was heated at $100^{\circ} \mathrm{C}$ for $12 \mathrm{~h}$, under magnetic stirring $(900 \pm 100 \mathrm{rpm})$. Afterward, the mixture was filtered and the excess alcohol (methanol or ethanol) was removed using a rotary evaporator (Rotavapor R-210, Büchi, Flawil, Switzerland). The glycerol formed as a by-product was easily separated by using a High-Speed refrigerated centrifuge (model CR22 N, Hitachi Koki Co., Ltd., Hitachikina-Ibaraki, Japan) for $10 \mathrm{~min}$ at $13,400 \times g$.

FAMEs and FAEEs were also produced by transesterification of the non-edible and waste oils: degummed macaw palm oil (FFAs content $=55.8 \mathrm{wt}$. $\%$, acid value $=111.0 \mathrm{mg} \mathrm{KOH} \mathrm{g}^{-1}$ ), degummed soybean oil (FFAs content $=3.6 \mathrm{wt}$. $\%$, acid value $=7.2 \mathrm{mg} \mathrm{KOH} \mathrm{g}^{-1}$ ), degummed palm oil (FFAs content $=4.9 \mathrm{wt} . \%$, acid value $=9.7 \mathrm{mg}$ $\mathrm{KOH} \mathrm{g}^{-1}$ ), waste soybean cooking oil (FFAs content $=1.5 \mathrm{wt} \%$, acid

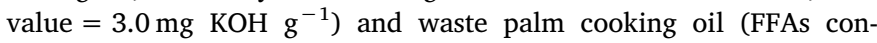
tent $=0.8 \mathrm{wt} . \%$, acid value $=1.6 \mathrm{mg} \mathrm{KOH}^{-1}$ ). The reactions were carried out in a closed steel pressure reactor (Parr Instrument Company, Illinois, USA) equipped with a mechanical stirrer set at $700 \pm 100 \mathrm{rpm}$. The reaction temperature $\left(150 \pm 5{ }^{\circ} \mathrm{C}\right)$ and the residence time $(6 \mathrm{~h})$ for these reactions resulted in maximum autogenic pressures of $8-10$ bar (methanolysis reaction) and 6-8 bar (ethanolysis reaction). Reusability experiments were performed using refined and waste cooking soybean oils (Glycine max). These experiments were performed under two conditions catalytic procedures: (a) the catalyst was immediately reused after the transesterification reaction without any treatment and (b) after each reaction cycle, the catalyst was subjected to a calcination treatment (air atmosphere at temperature of $500{ }^{\circ} \mathrm{C}$ for $3 \mathrm{~h}$, rate of $3{ }^{\circ} \mathrm{C} \mathrm{min}^{-1}$ ). The purpose of the calcination was to eliminate the glycerol byproduct from the catalytic sites of the stannosilicate, since its presence could hinder the transesterification reaction and consequently decrease the FAMEs yield $[9,35]$.

\subsection{Surface acidity measurements by FTIR of pyridine adsorption and TPD- $\mathrm{NH} 3$}

Surface acidity was measured by Fourier Transform Infrared (FTIR) spectroscopy of pyridine adsorption and temperature-programmed desorption of ammonia (TPD- $\mathrm{NH}_{3}$ ) using the facilities of the HumboldtUniversität zu Berlin (Institut für Chemie, Berlin, Germany). For the FTIR measurements, $75 \mathrm{mg}$ of the sample was preheated at $150{ }^{\circ} \mathrm{C}$ for $2 \mathrm{~h}$, under $\mathrm{N}_{2}$ flow. Afterward, $30 \mu \mathrm{L}$ of pyridine (Sigma-Aldrich, Steinheim, Germany) was chemisorbed on the material at $150{ }^{\circ} \mathrm{C}$ for $15 \mathrm{~min}$ and the FTIR spectra was recorded at room temperature using an MTEC cell and an FTIR system 2000 (Perkin-Elmer, Massachusetts, USA). Spectra of the samples before pyridine adsorption reactions were also measured as the background results. For the acidity measurement by TPD- $\mathrm{NH}_{3}$, the samples were pretreated at $500{ }^{\circ} \mathrm{C}$ for $2 \mathrm{~h}$. Afterward, ammonia was adsorbed onto the surface of the samples at $100{ }^{\circ} \mathrm{C}$ and its desorption $\left(10^{\circ} \mathrm{C} \min ^{-1}\right.$ up to $\left.500^{\circ} \mathrm{C}\right)$ was monitored by FTIR detection of the band at $930 \mathrm{~cm}^{-1}$. The amount of ammonia was determined by reaction with a solution of sulfur acid $\left(\mathrm{H}_{2} \mathrm{SO}_{4}\right)$ and titration with sodium hydroxide $(\mathrm{NaOH})$.

\subsection{Determination of the FAMEs and FAEEs contents by gas chromatography}

Chromatographic analyses were performed with a PerkinElmer Clarus 580 gas chromatograph (Perkin-Elmer, Massachusetts, USA) equipped with a flame ionization detector (GC-FID) using a RestekCarbowax capillary column (30 $\mathrm{m}$ long $\times 0.25 \mathrm{~mm}$ internal diameter). Gas chromatography analyses of the FAMEs and FAEEs in the biodiesel samples were performed using a sample injection volume of $1 \mathrm{~mL}$, helium as the carrier gas at a flow rate of $2 \mathrm{~mL} \mathrm{~min}^{-1}$ and pressure of $83 \mathrm{kPa}$, and injector and detector temperatures of $250^{\circ} \mathrm{C}$. The initial 
oven temperature was at $50^{\circ} \mathrm{C}$ (for $1 \mathrm{~min}$ ), followed by an increase to $250{ }^{\circ} \mathrm{C}$ at a rate of $5^{\circ} \mathrm{C} \min ^{-1}$. In a typical procedure, standard stock solutions of ethyl myristate (C14:0) and ethyl nervonate (C24:1) were prepared at concentrations of $20 \mathrm{mg} \mathrm{mL}^{-1}$, and an ethylic nonadecanoate standard stock solution was prepared at a concentration of $10 \mathrm{mg} \mathrm{mL}^{-1}$. The ethyl esters (C14:0 and C24:1) were used to identify the peak integration range and the ethylic ester (C19:0) was used as an internal standard (IS). The FAMEs and FAEEs contents were obtained by integrating the peak areas from C14:0 to C24:1 and subtracting the nonadecanoate peak area, according to the following equation:

$C=\frac{\sum A-A_{I S}}{A_{I S}} x \frac{C_{I S}-V_{I S}}{m} x 100 \%$

where,

$\Sigma \mathrm{A}=$ sum of the areas of all peaks in the range from C14:0 to C24:0;

$\mathrm{A}_{\mathrm{IS}}=\mathrm{C} 19: 0$ internal standard peak area;

$\mathrm{C}_{\mathrm{IS}}=$ concentration $\left(\mathrm{mg} \mathrm{mL}^{-1}\right)$ of the C19:0 solution;

$\mathrm{V}_{\mathrm{IS}}=$ volume of the C19:0 solution added to the sample;

$\mathrm{m}=$ mass of the sample (mg).

\section{Results and discussion}

\subsection{Physicochemical characterization of the stannosilicate synthesized}

OPTs microporous silicates are in general prepared under hydrothermal conditions ranging from $c a .120$ to $230{ }^{\circ} \mathrm{C}$ and times varying between a few hours and $c a .30$ days. In this study, the synthesis of the metallo-stannosilicate was investigated at $200{ }^{\circ} \mathrm{C}$ with a time interval ranging from 2 to 42 days. The XRD pattern of the as-synthesized stannosilicate, as a result of different reaction times, are displayed in Fig.1. It can be observed that at 2 days at $200{ }^{\circ} \mathrm{C}$ the main phases of the material are formed, although it shows poor crystallinity. However, after 4 days of synthesis, the material is completely formed and it kept its crystallinity, and no other impurity or concurrent phase is formed, even when the synthesis was kept for 42 days at $200^{\circ} \mathrm{C}$. The XRD pattern, for the sample prepared at 42 days at $200^{\circ} \mathrm{C}$, detailed in the inset of Fig. 1, shows that the as-synthesized stannosilicate corresponded to a crystalline material, with the main Bragg reflections in the $2 \theta$ range $7.5-40^{\circ}$, characteristic of a microporous mixed OPT (Octahedral-Pentahedral-Tetrahedral) framework silicate structure $[17,36]$.

Indexation of the main diffraction peaks of the sample prepared at $200{ }^{\circ} \mathrm{C}$ for 21 days using TREOR software [37] resulted in an orthor-

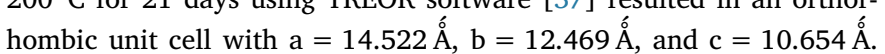
The material obtained differed from other main stannosilicates reported in the literature, such as the stannosilicates Sn-A, Sn-B and Sn-L

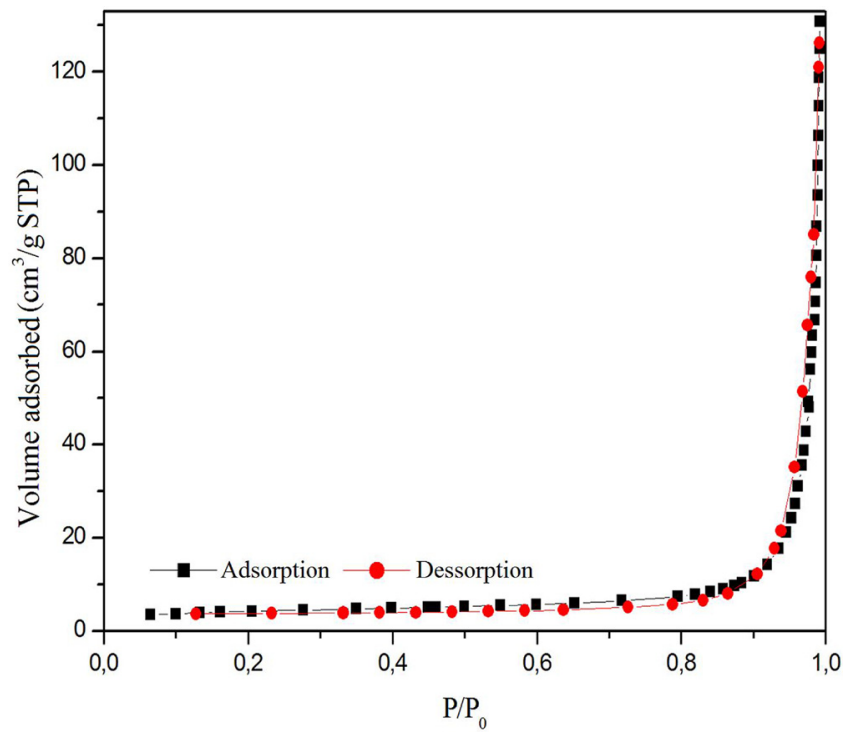

Fig. 2. BET-N $\mathrm{N}_{2}$ adsorption isotherm of the stannosilicate.

reported by Corcoran et al. [21,22], the stannosilicate family AV-10, AV-11, AV-13 and AV-14 reported by Rocha et al., [38-41] and the stannosilicate EMS-2, described by Millini et al. [42]. The XRD pattern showed no evidence of tin oxide or a sodium stannate formation, with no diffraction peaks attributable to a $\mathrm{SnO}_{2}$ phase (JCPDS 41-1445) or $\mathrm{Na}_{2} \mathrm{SnO}_{3} \cdot 3 \mathrm{H}_{2} \mathrm{O}$ (JCPDS 01-1115).

Chemical analysis by Energy dispersive X-ray spectroscopy (EDS) showed atomic compositions of $\mathrm{Si}=15.5 \pm 0.8 \%, \mathrm{Sn}=3.7 \pm 0.1 \%$ and $\mathrm{Na}=13.3 \pm 1.8 \%$, resulting in $\mathrm{Si}: \mathrm{Sn}=4.2$ and $\mathrm{Na}: \mathrm{Sn}=3.6$ ratios. BET- $\mathrm{N}_{2}$ adsorption isotherm of the stannosilicates synthesized, showed in Fig. 2, and the calculated microporous volume of $0.048 \mathrm{~cm}^{3}$, $\mathrm{g}$, indicated that the porous of this material are small, probably a consequence of its dense structure. The material presents a low surface area of $14.8 \mathrm{~m}^{2} / \mathrm{g}$ when compared to $41.6 \mathrm{~m}^{2} / \mathrm{g}$ for the small-pore framework sodium stannosilicate AV-10 [38] and with values reported in the literature for $\mathrm{SnO}_{2}$ nanoparticles synthesized by different methods [43-45]. The line broadening in the powder XRD pattern of the stannosilicate could be due to the small particles size of the sample: SEM and AFM images of the stannosilicates obtained at 7, 21 and 42 days at $200{ }^{\circ} \mathrm{C}$ indicated that the sample is formed by small plates aggregates, as shown in Fig. 3 (particle size ranging from $100 \mathrm{~nm}$ to $300 \mathrm{~nm})$.

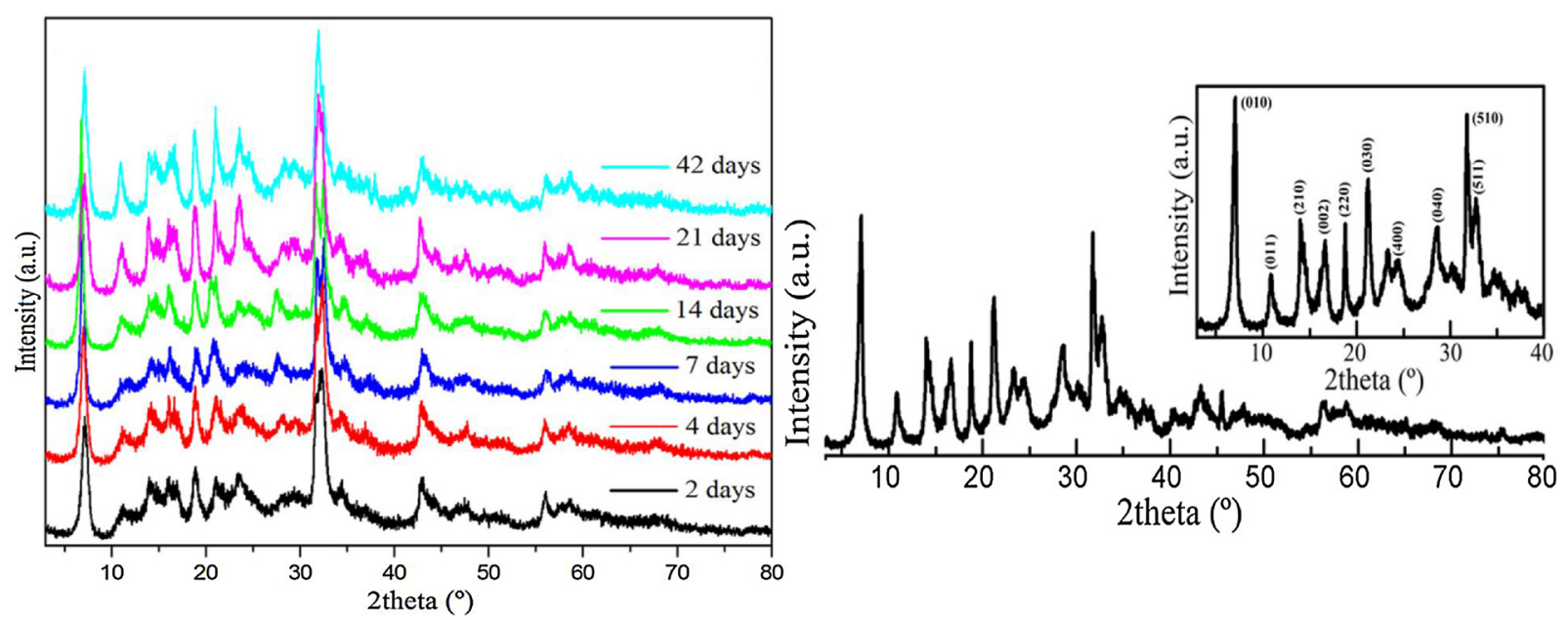

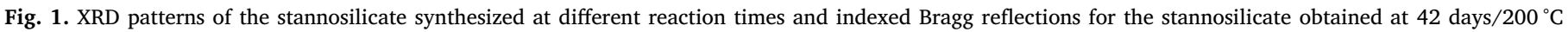
(inset). 


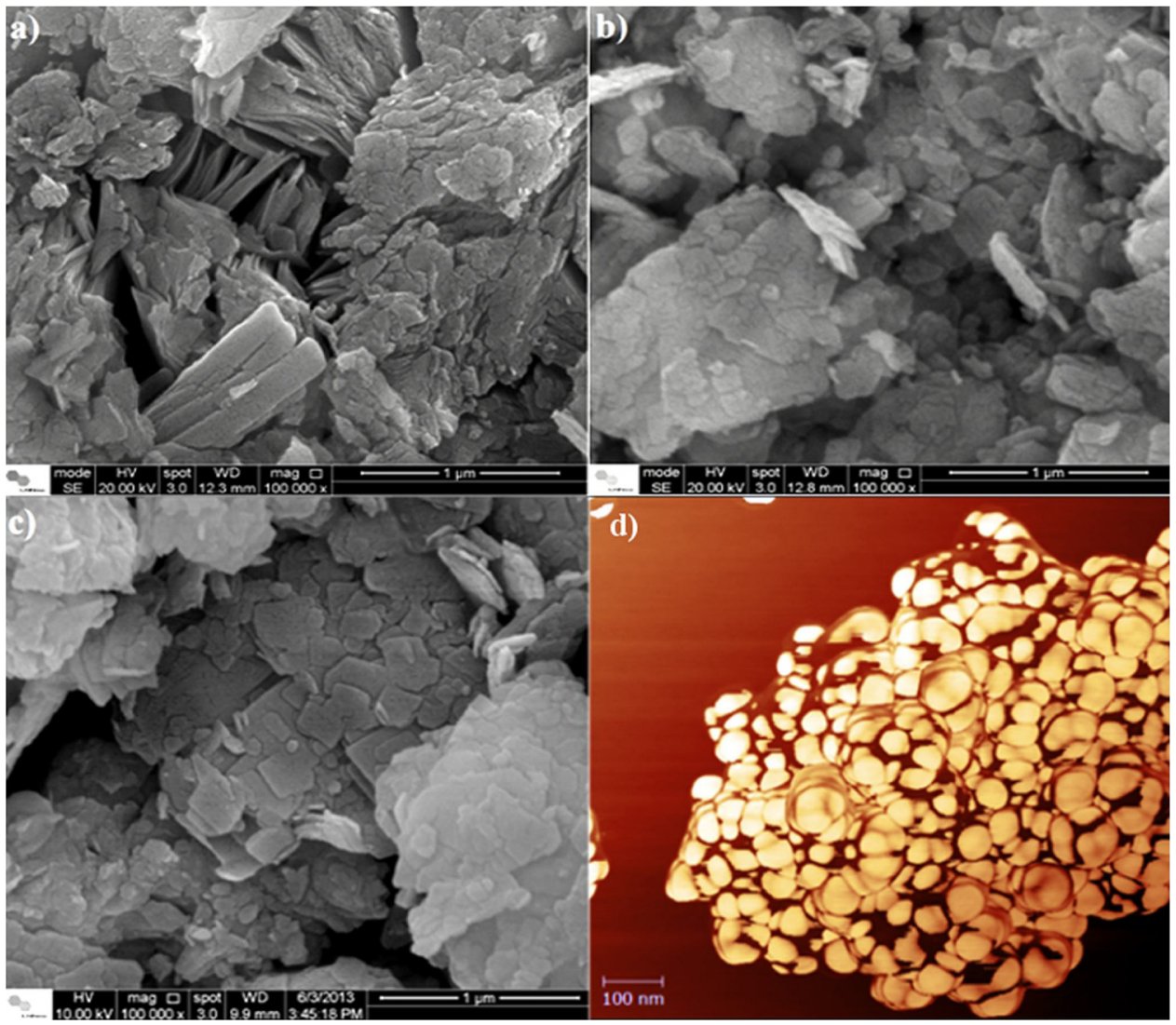

Fig. 3. Scanning electron microscopy (SEM) images of stannosilicates synthesized at (a) 7 days, (b) 21 days, (c) 42 days and (d) Atomic force microscopy (AFM) image.
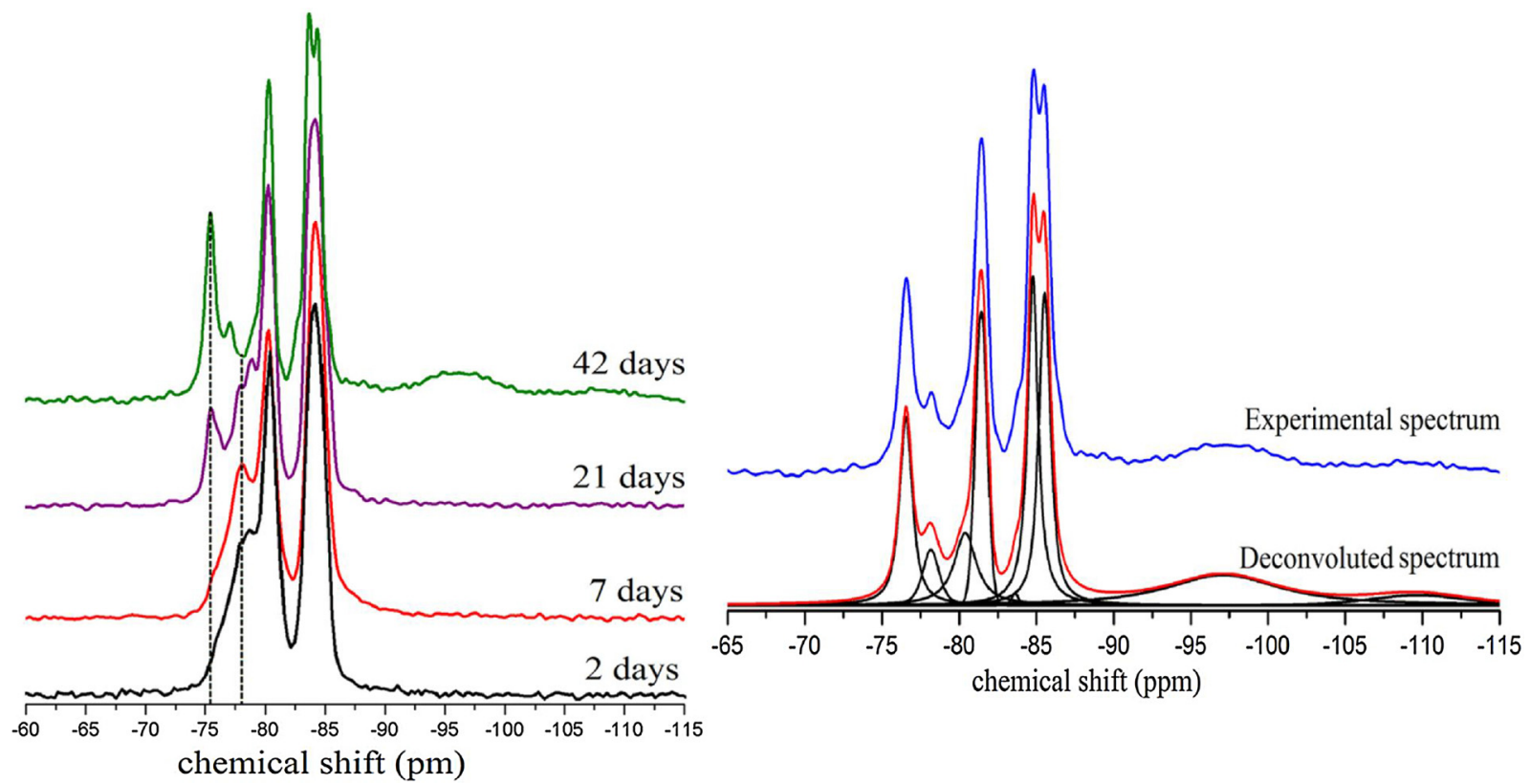

Fig. 4. Characteristic ${ }^{29} \mathrm{Si}$ single-pulse MAS NMR spectra obtained for stannosilicate synthesized at different reaction times. Detailed deconvoluted spectrum of the stannosilicate prepared at 42 days $/ 200^{\circ} \mathrm{C}$.

${ }^{29} \mathrm{Si}$ single-pulse MAS NMR studies of the stannosilicate obtained at 4, 7, 21 and 42 days at $200{ }^{\circ} \mathrm{C}$ was performed and the spectra are shown in Fig.4. Although the XRD data revealed that the same material was obtained at 4-42 days at $200{ }^{\circ} \mathrm{C}$, analysis of the ${ }^{29} \mathrm{Si}$ single-pulse MAS NMR spectra revealed a more complex local symmetry disorder is occurring. The deconvoluted ${ }^{29} \mathrm{Si}$ single-pulse MAS NMR spectrum of the sample prepared at 42 days at $200{ }^{\circ} \mathrm{C}$ is shown in the inset of Fig. $4 .{ }^{29} \mathrm{Si}$ environment assignment was based on the seminal research for ${ }^{29} \mathrm{Si}$ solid-state MAS NMR of aluminosilicates structures [46,47]. Nine resonance lines were present, with the following chemical shift values: $\delta_{1}=-76.5 \mathrm{ppm}, \delta_{2}=-78.1 \mathrm{ppm}, \delta_{3}=-80.3 \mathrm{ppm}, \delta_{4}=-81.4 \mathrm{ppm}$, $\delta_{5}=-83.6 \mathrm{ppm}, \quad \delta_{6}=-84.7 \mathrm{ppm}, \quad \delta_{7}=-85.5 \mathrm{ppm}, \delta_{8}=$ 


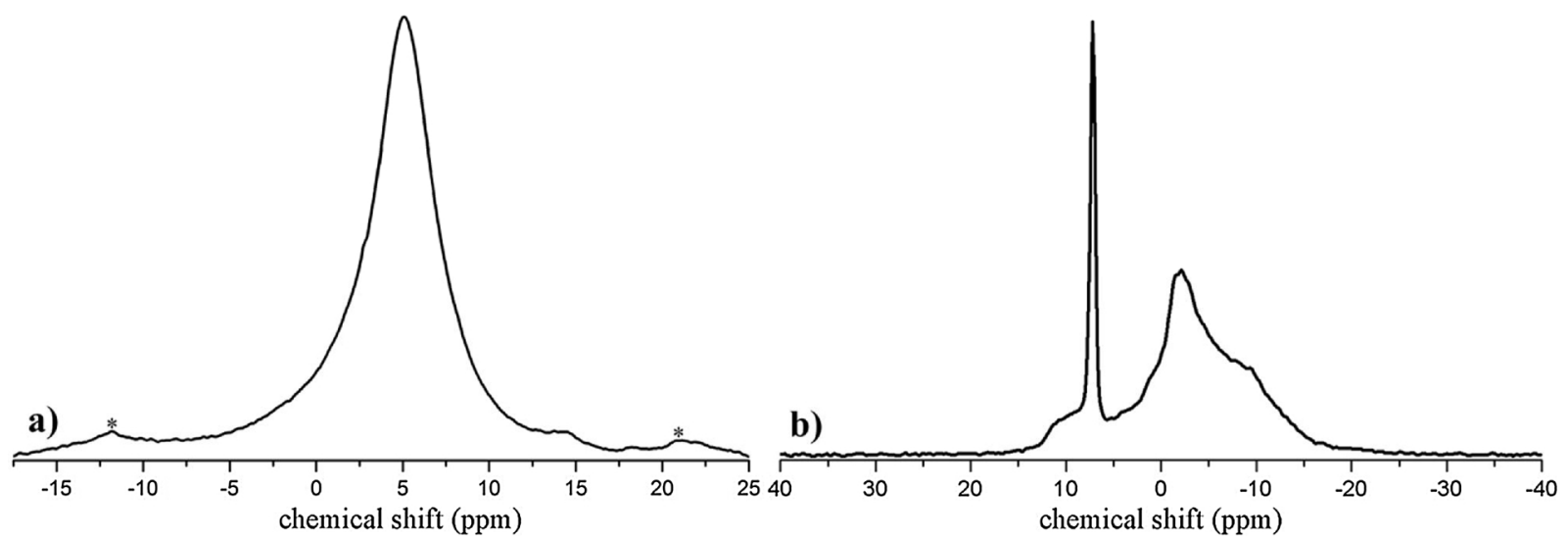

Fig. 5. (a) ${ }^{1} \mathrm{H}$ and (b) ${ }^{23} \mathrm{Na}$ single-pulse MAS NMR spectra of the stannosilicate (*spinning sidebands, MAS frequency $=6.5 \mathrm{KHz}$ ).

$-97.1 \mathrm{ppm}$, and $\delta_{9}=-109.7 \mathrm{ppm}$. These chemical shifts differed from those described in literature, as the obtained for the AV-10 stannosilicate [38], where the spectrum showed two chemical shifts, at $\delta_{1}=$ $-87.0 \mathrm{ppm}$ and $\delta_{2}=-88.7 \mathrm{ppm}$, with relative intensities of $1: 2$, associated with the $\mathrm{Si}(2 \mathrm{Si}, 2 \mathrm{Sn})$ environment. Rocha et al. [40] reported a broad resonance ${ }^{29} \mathrm{Si}$ spectrum for AV-13 material, with chemical shift value at $\delta=-87.1 \mathrm{ppm}$, which calls for the presence of a single $\mathrm{Si}$ $(2 \mathrm{Si}, 2 \mathrm{Sn})$ site. Corcoran et al. $[21,22]$ reported ${ }^{29} \mathrm{Si}$ chemical shifts for the three stannosilicate phases prepared by them, at $\delta_{1}=-88.0 \mathrm{ppm}$ and $\delta_{2}=-90.3 \mathrm{ppm}(\mathrm{Sn}-\mathrm{A}), \delta_{1}=-89.0 \mathrm{ppm}(\mathrm{Sn}-\mathrm{B})$, and $\delta_{1}=$ $-82.6 \mathrm{ppm}$ and $\delta_{2}=-87.2 \mathrm{ppm}$ (Sn-L). Millini et al. [42] reported three well-resolved ${ }^{29} \mathrm{Si}$ peaks for the EMS-2 stannosilicate: $\delta_{1}=$ $-90 \mathrm{ppm}, \delta_{2}=-99 \mathrm{ppm}$ and $\delta_{3}=-112 \mathrm{ppm}$. Based on the reported ${ }^{29} \mathrm{Si}$ chemical shift values and the XRD diffraction results, it is evident that the stannosilicate obtained in this study is different from those reported in the literature.

Considering that the catalytic studies were systematically done with the stannosilicate obtained at 21 days at $200{ }^{\circ} \mathrm{C}$, a more detailed analysis of ${ }^{1} \mathrm{H},{ }^{23} \mathrm{Na}$ and ${ }^{119} \mathrm{Sn}$ single-pulse MAS NMR spectra of this sample was performed. The ${ }^{1} \mathrm{H}$ MAS NMR spectrum of the stannosilicate (Fig. 5a) showed only one broad resonance line at $\delta_{2}=4.8 \mathrm{ppm}$, associated with the presence of structural water molecules $[47,48]$. The ${ }^{23} \mathrm{Na}$ single-pulse MAS NMR spectrum (Fig. 5b) presented a chemical shift at around $\delta=7.4 \mathrm{ppm}$, which could be attributed to the formation of $\mathrm{NaCl}$, as reported by Hunger et al. [49]. The role of sodium in the synthesis of stannosilicates and tin zeolites has been discussed in the literature and one of the conclusions reached is that interactions among the sodium and tin cations can lead to the formation of sodium stannate as an impure phase [50], however XRD analysis showed no evidence of this impure phase (JCPDS 01-1115). Attempts to assign the resonance lines with greater accuracy were unsuccessful, due to the difficult task of performing the spectrum deconvolution (Fig. 5b), considering the quadrupolar nature of the sodium $\left({ }^{23} \mathrm{Na}\right)$ nucleus.

The ${ }^{119} \mathrm{Sn}$ single-pulse MAS NMR spectrum (Fig. 6) presented two resonance lines, at $\delta_{1}=-683.8 \mathrm{ppm}$ and $\delta_{2}=-690.9 \mathrm{ppm}$, which could be assigned to tin species in the $\mathrm{Sn}^{4+}$ oxidation state, indicating that the tin atoms were octahedrally coordinated in the stannosilicate structure [34,38,51]. The ${ }^{119} \mathrm{Sn}$ single-pulse MAS NMR analysis indicated that $\mathrm{Sn}^{2+}$ was oxidized to $\mathrm{Sn}^{4+}$ during the hydrothermal crystallization. It is entirely possible that $\mathrm{Sn}^{2+}$ acted as a reducing agent during the course of the hydrothermal crystallization. $\mathrm{Sn}^{2+}$ is a strong reducing agent and in the presence of a strongly alkaline solution it can cause the formation of tetrahydroxystannate species, according to the following chemical reaction: $\mathrm{Sn}^{2+}+4 \mathrm{OH}^{-}=\left(\mathrm{Sn}(\mathrm{OH})_{4}\right)^{2-}$.

\subsection{Transesterification reactions of edible, non-edible and waste oils}

Transesterifications reactions were performed according to the experimental conditions described in Section 2.4 using the stannosilicate at 21 days at $200^{\circ} \mathrm{C}$; however, experimental evidence acquired throughout this study lead to the conclusion that depending on the triacylglycerides feedstocks, two types of reactors were a need to obtain the best FAMEs or FAEEs yields. For refined edible and non-edible vegetable oils (average FFAs content $\leq 0.3 \mathrm{wt}$. \%, and acid value $\leq$ $0.6 \mathrm{mg} \mathrm{g}^{-1}$ ), a typical reactor (an open glass reactor equipped with a reflux condenser and a magnetic stirrer, immersed in a thermostatic bath) was used, while for degummed vegetable and waste cooking oils (average FFAs content $\leq 55.8 \mathrm{wt}$. \%, and acid value $\leq 111 \mathrm{mg} \mathrm{g}^{-1}$ ) was utilized a closed steel pressure reactor (Parr Instrument Company, Illinois, USA) equipped with a mechanical stirrer.

The FAMEs and FAEEs yields obtained in the transesterification reactions of the refined edible and non-edible vegetable oils are shown in Table 1. The catalytic conversions of the refined soybean, corn, canola, and sunflower oils exceeded $90.0 \%$ for FAMEs and FAEEs. A lower FAEEs yield of $82.6 \%$ was obtained with the refined palm oil. It is interesting to note the higher FAMEs and FAEEs yields obtained using microalgae oil, compared to the other triacylglyceride feedstocks. According to several critical reviews [52-55], biodiesel production from oil crops, waste cooking oil, and animal fat cannot satisfy even a small fraction of the existing demand for transport fuels, and microalgae appear to be the only source of renewable biodiesel capable of meeting the global transport fuel demand [52,53]. To the best of our knowledge, there is no report in the scientific or patent literature reporting the use of heterogeneous catalyst based on metallo-stannosilicate on the transesterification of microalgae oils using both the methanolysis or ethanolysis processes.

Due to the fact that the transesterification reactions of the non-edible and waste oils were performed in a closed steel reactor $\left(150 \pm 5{ }^{\circ} \mathrm{C}\right.$ for $\left.6 \mathrm{~h}\right)$, the generated autogenous pressure derived from the closed nature of the container was similar for both the methanolysis (8-10 bar) and ethanolysis (6-8 bar) reactions. The FAMEs and FAEEs yields obtained for these reactions are displayed in Table 2. Transesterification with degummed soybean oil (3.6 wt. \% of FFAs, acid value $=7.2 \mathrm{mg} \mathrm{KOH}^{-1}$ ) resulted in a FAMEs yield of $82.0 \%$, while the yield of FAEEs was about $20.3 \%$. The same pattern was repeated with degummed palm oil (FFAs content of $4.9 \mathrm{wt}$. \%, acid value $=9.7$ $\mathrm{mg} \mathrm{KOH}{ }^{-1}$ ) with yields of $59.5 \%$ and $10.6 \%$ for FAMEs and FAEEs, respectively. The FAMEs and FAEEs yields for degummed macaw palm oil (FFAs content $=55.8 \mathrm{wt}$. $\%$, acid value $=111.0 \mathrm{mg} \mathrm{KOH} \mathrm{g}^{-1}$ ) were $65.5 \%$ and $30.9 \%$ respectively, and the results provide clear evidence of the potential of the stannosilicate for simultaneous use as a heterogeneous catalyst in both esterification and transesterification reactions involving low-quality raw materials and by methanolysis and ethanolysis reactions. Although several reports are describing simultaneous esterification and transesterification of vegetable oils using tin-based catalysts $[25,28-30,56-58]$, none of the studies were performed with 


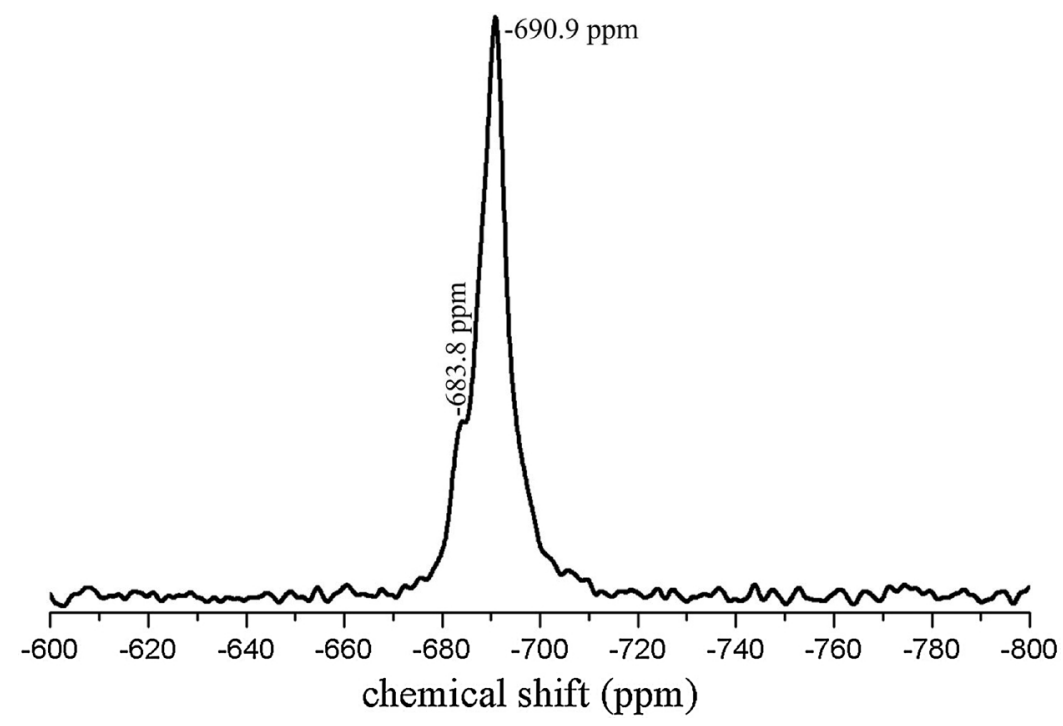

Fig. $6 .{ }^{119} \mathrm{Sn}$ single-pulse MAS NMR spectrum of the stannosilicate.

degummed macaw palm oil as feedstocks.

Table 3 summarizes the studies reported in the literature that have used tin-based catalysts in methanolysis and ethanolysis reactions for biodiesel production, and a comparison of the FAMEs and FAEEs obtained in this study. Serra et al. [25] used commercial Lewis acid Sn(IV) compounds in the transesterification of refined soybean oil and obtained a maximum FAMEs yield of around $23.0 \%$, while here the stannosilicate provided a FAMEs yield of $99.5 \%$. Abreu et al. [23] tested several catalysts based on transition metals, including $\mathrm{Sn}$ $\left(\mathrm{C}_{6} \mathrm{H}_{5} \mathrm{O}_{3}\right)_{2}\left(\mathrm{H}_{2} \mathrm{O}\right)_{2}, \mathrm{Zn}\left(\mathrm{C}_{6} \mathrm{H}_{5} \mathrm{O}_{3}\right)_{2}\left(\mathrm{H}_{2} \mathrm{O}\right)_{2}, \mathrm{~Pb}\left(\mathrm{C}_{6} \mathrm{H}_{5} \mathrm{O}_{3}\right)_{2}\left(\mathrm{H}_{2} \mathrm{O}\right)_{2}$, and $\mathrm{Hg}$ $\left(\mathrm{C}_{6} \mathrm{H}_{5} \mathrm{O}_{3}\right)_{2}\left(\mathrm{H}_{2} \mathrm{O}\right)_{2}$, in the transesterification of refined soybean oil and found that the tin-based catalyst was most active: the FAMEs yield was $93.8 \%$, closed to the values obtained using the stannosilicate in the present work. A similar FAMEs yield (89.2\%) was reported by Casas et al. [28] who employed tin(II) acetate $\left(\mathrm{Sn}\left(\mathrm{C}_{6} \mathrm{H}_{5} \mathrm{O}_{3}\right)_{2}\left(\mathrm{H}_{2} \mathrm{O}\right)_{2}\right)$ in the transesterification of sunflower oil to biodiesel production.

Solid acids catalysts have been established as being other alternatives to the heterogeneous alkaline, unrecyclable-homogeneous acid and alkaline catalysts [59-62], and since the seminal work of Chavan et al. [63] and Matsuhashi et al. [64] on the esterification of $B$ Keto ester, tin-based catalysts was related to the strong acidity on its surface. In the case of the metallo-stannosilicate reported in this study, the experimental results for FTIR of pyridine adsorption and temperatureprogrammed desorption of ammonia (TPD- $\mathrm{NH}_{3}$ ) revealed a very weak acidity (Fig.7). Characteristic IR-bands of adsorbed pyridine related to the strength and quantity of both Lewis and Bronsted acid sites were not observed on the stannosilicate surface. According to the literature, the bands $1453 \mathrm{~cm}^{-1}$ and $1622 \mathrm{~cm}^{-1}$ are associated with the interaction between the pyridine molecule and Lewis sites, the bands $1545 \mathrm{~cm}^{-1}$ and $1645 \mathrm{~cm}^{-1}$ are associated with Bronsted sites, while $1493 \mathrm{~cm}^{-1}$ and $1580 \mathrm{~cm}^{-1}$ are associated to both Lewis and Bronsted sites [65]. The low amount of ammonia desorbed on the catalyst surface $=1.1$ $\times 10^{-2} \mu \mathrm{mol} \mathrm{g}^{-1}$ ) corroborates the low acidity of this stannosilicate.

It is quite possible that the catalytic activity of the synthesized stannosilicate is associated with the basicity induced by the sodium
Table 2

FAMEs and FAEEs yields obtained for the transesterification reactions with waste cooking and degummed vegetable oils. Reactions were performed in a closed steel pressure reactor; temperature $=150^{\circ} \mathrm{C}$; oil:alcohol molar ratio $=$ $1: 30$; reaction time $=6 \mathrm{~h} ; 3 \%$ of catalyst (relative to the mass of oil).

\begin{tabular}{|c|c|c|c|c|c|}
\hline \multirow[t]{2}{*}{ Feedstocks } & \multicolumn{2}{|c|}{$\begin{array}{l}\text { Soybean oil } \\
\text { (Glycine max) }\end{array}$} & \multicolumn{2}{|c|}{$\begin{array}{l}\text { Palm oil } \\
\text { (Elaeis guineensis) }\end{array}$} & \multirow{2}{*}{$\begin{array}{l}\text { Macaw palm oil } \\
\text { (Acrocomia } \\
\text { aculeata) }\end{array}$} \\
\hline & Waste & Degummed & Waste & Degummed & \\
\hline $\begin{array}{l}\text { FAMEs yield } \\
\text { (\%) }\end{array}$ & 99.0 & 82.0 & 91.2 & 59.5 & $66.5^{\mathrm{a}}$ \\
\hline FAEEs yield (\%) & 70.2 & 20.3 & 71.3 & 10.6 & $30.9^{2}$ \\
\hline
\end{tabular}

Methanolysis reaction (autogenic pressure $=8-10$ bar)Ethanolysis reaction (autogenic pressure $=6-8$ bar).

${ }^{\mathrm{a}}$ Final free fatty acid (FFAs) content $=23.5 \mathrm{wt} .{ }^{2}{ }^{2}$ Final free fatty acid (FFAs) content $=32.1 \mathrm{wt} . \%$.

species present in the crystalline structure of this material. The weak acidity measured by temperature-programmed desorption of ammonia (TPD-NH $\mathrm{N}_{3}$ ) (Fig.7b) and the ${ }^{23} \mathrm{Na}$ single-pulse MAS NMR spectrum (Fig. 5b) showing evidence of the formation of polymeric sodium species, corroborate this assumption. Several studies have also reported the effect of the basicity of sodium-based catalysts [66-70]. Zhang et al. [67] described the synthesis of a sodium stannate with a high concentration of basic sites and high catalytic activity in transesterification reactions of a cyclic carbonate with methanol. Marciniuk et al. [68] reported the application of sodium titanate as a basic catalyst in the transesterification of ethyl acetate with ethanol. Guo et al. [70] synthesized a sodium silicate (19.3-22.8 wt. \% of $\mathrm{Na}_{2} \mathrm{O}$ ) used as a heterogeneous catalyst in the transesterification of soybean oil, achieving a FAMEs yield of around $100 \%$ under experimental conditions similar to those used in the present work.

Reuse experiments were performed with the refined and waste cooking soybean oil as the lipid feedstock in the methanolysis route. The results obtained with the refined soybean oil (Fig. 8a) showed that

Table 1

FAMEs and FAEEs yields obtained for the transesterification reactions with refined vegetable oils. Reactions were performed using an open glass reactor at atmospheric pressure; temperature $=100^{\circ} \mathrm{C}$; oil:alcohol molar ratio $=1: 30$; reaction time $=12 \mathrm{~h} ; 3 \%$ of catalyst (relative to the mass of oil).

\begin{tabular}{|c|c|c|c|c|c|c|}
\hline Refined oils & Palm oil & Soybean oil & Corn oil & Canola oil & Sunflower oil & Microalgae oil \\
\hline FAMEs yield (\%) & 99.5 & 99.5 & 96.0 & 97.6 & 95.8 & 98.2 \\
\hline FAEEs yield (\%) & 82.6 & 90.2 & 93.8 & 95.0 & 94.8 & 96.6 \\
\hline
\end{tabular}


Table 3

Examples of tin-based heterogeneous catalysts used in the transesterification reactions of vegetable oils into biodiesel.

\begin{tabular}{|c|c|c|c|c|c|c|c|c|}
\hline Feedstock & Catalyst & Alcohol & Alcohol:oil & $\begin{array}{l}\text { Catalyst loading } \\
\text { (wt.\%) }\end{array}$ & Temperature $\left({ }^{\circ} \mathrm{C}\right)$ & Time (h) & Yield (\%) & Reference \\
\hline \multirow{7}{*}{$\begin{array}{l}\text { Refined } \\
\quad \text { soybean oil }\end{array}$} & Stannosilicate & Methanol & $30: 1$ & 3 & 100 & 12 & 99.5 & Present work \\
\hline & Stannosilicate & Ethanol & $30: 1$ & 3 & 100 & 12 & 90.2 & Present work \\
\hline & $\mathrm{Sn}$ (3-hydroxy-2-methyl-4-pyrone $)_{2}\left(\mathrm{H}_{2} \mathrm{O}\right)_{2}$ & Methanol & 400:100:1 & - & 60 & 5 & 93.8 & {$[23]$} \\
\hline & Dibutyltin dilaurate & Methanol & 400:100:1 & - & 80 & 10 & 43.1 & [24] \\
\hline & Dibutyltin diacetate & Methanol & 400:100:1 & - & 60 & 4 & 23.0 & {$[25]$} \\
\hline & Dibutyltin diacetate & Methanol & 400:100:1 & - & 150 & 4 & 79.0 & {$[25]$} \\
\hline & $\mathrm{SnO}_{2} / \mathrm{SiO}_{2}$ & Methanol & $24: 1$ & 5 & 180 & 5 & 81.7 & {$[26]$} \\
\hline \multirow{4}{*}{$\begin{array}{l}\text { Refined } \\
\text { palm oil }\end{array}$} & Stannosilicate & Methanol & 30:1 & 3 & 100 & 12 & 99.5 & Present work \\
\hline & Stannosilicate & Ethanol & $30: 1$ & 3 & 100 & 12 & 82.6 & Present work \\
\hline & Stannosilicate & Ethanol & $30: 1$ & 3 & 150 & 6 & 99.5 & Present work \\
\hline & $\mathrm{Sn}$ (3-hydroxy-2-methyl-4-pyrone $)_{2}\left(\mathrm{H}_{2} \mathrm{O}\right)_{2}$ & Methanol & 400:100:1 & - & 60 & 1 & 16.2 & [27] \\
\hline \multirow{4}{*}{$\begin{array}{l}\text { Refined } \\
\quad \text { sunflower oil }\end{array}$} & Stannosilicate & Methanol & $30: 1$ & 3 & 100 & 12 & 95.8 & Present work \\
\hline & Stannosilicate & Ethanol & $30: 1$ & 3 & 100 & 12 & 94.8 & Present work \\
\hline & Tin(II) acetate & Methanol & $30: 1$ & 0.15 & 100 & 1 & 46.4 & {$[28]$} \\
\hline & Tin(II) acetate & Methanol & $30: 1$ & 0.15 & 150 & 1 & 89.2 & {$[28]$} \\
\hline \multirow{4}{*}{$\begin{array}{l}\text { Waste } \\
\text { soybean cooking } \\
\quad \text { oil }\end{array}$} & Stannosilicate & Methanol & 30:1 & 3 & 150 & 6 & 99.0 & Present work \\
\hline & Stannosilicate & Ethanol & $30: 1$ & 3 & 150 & 6 & 70.2 & Present work \\
\hline & $\mathrm{SO}_{4}{ }^{2-} / \mathrm{SnO}_{2}-\mathrm{SiO}_{2}$ & Methanol & 15 & 6 & 150 & 1.5 & 88.2 & [30] \\
\hline & $\mathrm{SO}_{4}{ }^{2-} / \mathrm{SnO}_{2}-\mathrm{SiO}_{2}$ & Methanol/ethanol & $9-6: 1$ & 6 & 150 & 1 & 81.4 & {$[29]$} \\
\hline
\end{tabular}

the calcined stannosilicate maintained a FAMEs yield of around $90.0 \%$ after four reaction cycles, while the yield achieved with the non-calcined catalyst decreased sharply to $38.7 \%$ after three reaction cycles. Meanwhile, the results for the waste cooking oil using the calcined catalyst (Fig. 8b) indicated FAMEs yields of $\geq 90.0 \%$ in the first three cycles, after which the yield progressively decreased to $35.2 \%$ in the sixth cycle. The findings reported here using the synthesized stannosilicate are novel and demonstrate the considerable potential of this material in the field of biodiesel research.

\section{Conclusions}

A metallo-stannosilicate was obtained by hydrothermal synthesis and fully characterized by powder XRD, electron microscopy (SEM) and solid-state MAS NMR $\left({ }^{1} \mathrm{H},{ }^{23} \mathrm{Na},{ }^{29} \mathrm{Si}\right.$ and ${ }^{119} \mathrm{Sn}$ MAS NMR $)$. High yields of FAMEs and FAEEs were obtained using the metallo-stannosilicate as heterogeneous catalyst in the transesterification reactions of refined edible, non-edible, and waste oils. In comparison with several non-edible lipid feedstocks, the highest FAEEs yields were obtained non-edible microalgae oil extracted from the genetically modified heterotrophic algal Prototheca moriformis. Catalytic tests using non-edible macaw palm oil (Acrocomia aculeate) with a high content of FFAs indicated that the catalyst could simultaneously perform esterification and transesterification reactions. The experimental results obtained with this new material indicated its potential for being used as a heterogeneous catalyst in the production of clean, renewable and environmentally friendly biofuels with different kinds of lipid feedstocks, notably those that do not compete with food production.

\section{Acknowledgments}

We thank the State of São Paulo Research Foundation (FAPESP) and National Council for Scientific and Technological Development (CNPq) for the grant awards \#11/51851-5 and \#406761/2013-2, respectively. D.A.S. thanks CAPES for his fellowship (Proc. $\mathrm{n}^{\circ}$ BEX 2428/15-6). We acknowledge Dr. Franziska Emmerling and Mr. Carsten Prinz (BAM, Division 1.3. Structural Analysis) for the BET- $\mathrm{N}_{2}$ measurements, Prof. Dr. Erhard Kemnitz and Dr. Kerstin Scheurell (Humboldt Universität zu Berlin, Institut für Chemie) for the FTIR-Pyridine and TPD-NH $\mathrm{N}_{3}$ measurements. We appreciate the assistance of Dr. Jefferson Bettini, Dr. Carlos A. O. Ramirez and Dr. Carlos A. Costa (Brazilian National Laboratory of Nanotechnology, LNNano) for the SEM and AFM
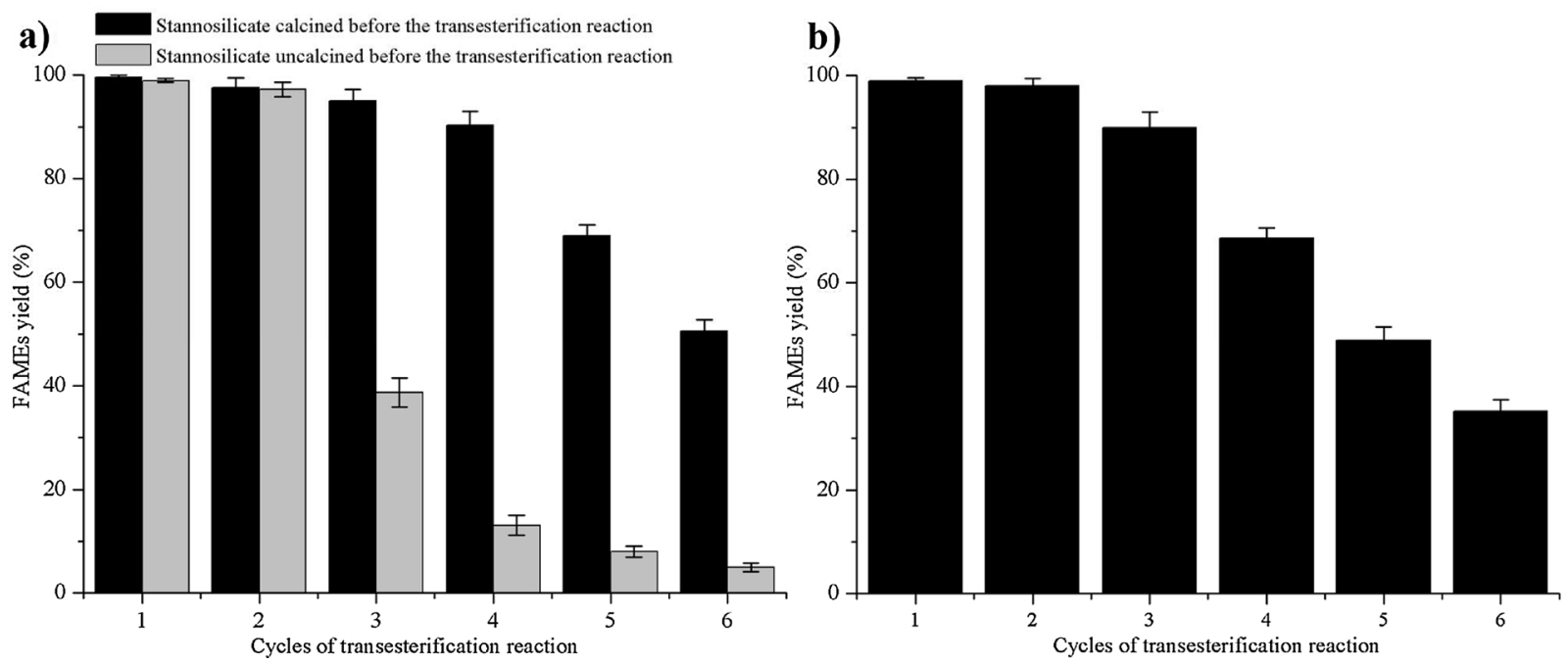

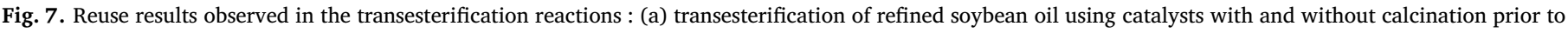
the catalytic reaction; (b) use of the calcined stannosilicate in transesterification of waste cooking soybean oil. 

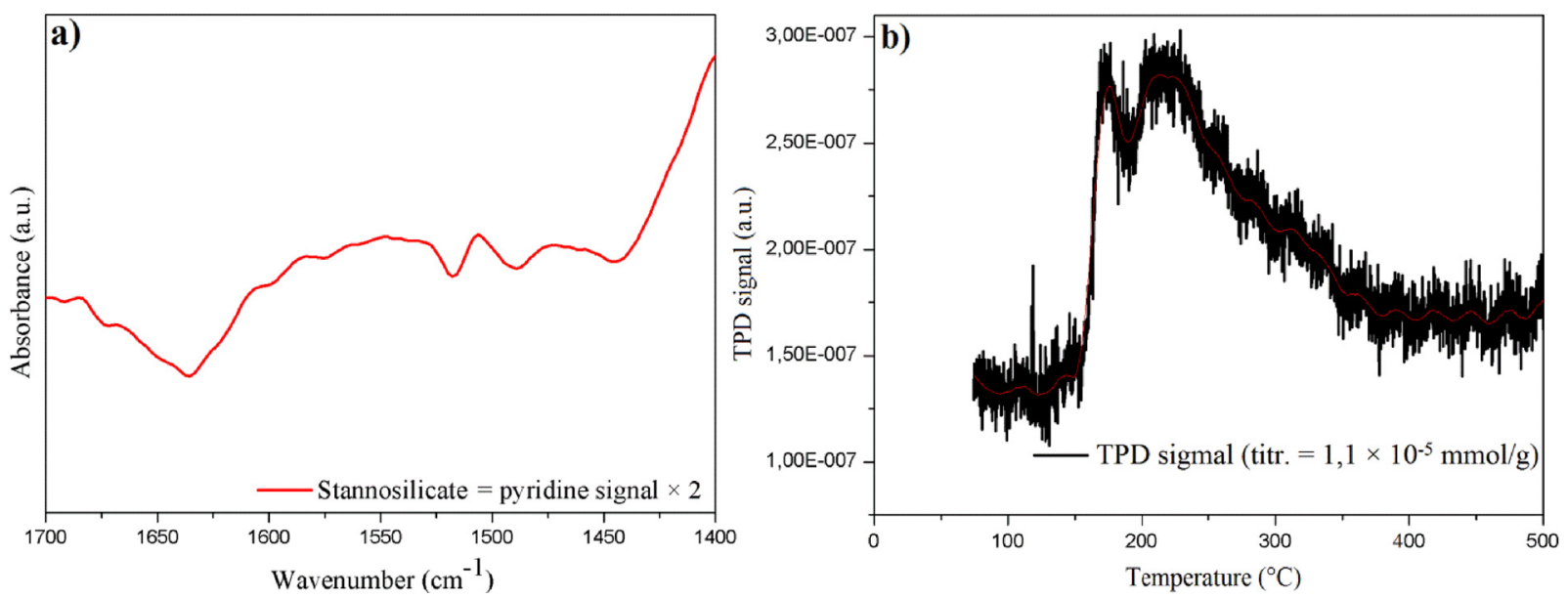

Fig. 8. Surface acidity measurements of the stannosilicate: (a) FTIR spectroscopy of pyridine adsorption and (b) temperature-programmed desorption of ammonia $\left(\mathrm{TPD}-\mathrm{NH}_{3}\right)$.

microscopy experiments.

\section{References}

[1] S.P. Singh, D. Singh, Biodiesel production through the use of different sources and characterization of oils and their esters as the substitute of diesel: a review, Renew. Sustain. Energy Rev. 14 (2010) 200-216, https://doi.org/10.1016/J.RSER.2009. 07.017.

[2] M. Balat, Potential alternatives to edible oils for biodiesel production - a review of current work, Energy Convers. Manag. 52 (2011) 1479-1492, https://doi.org/10. 1016/j.enconman.2010.10.011.

[3] M.M. Gui, K.T. Lee, S. Bhatia, Feasibility of edible oil vs. Non-edible oil vs. Waste edible oil as biodiesel feedstock, Energy 33 (2008) 1646-1653, https://doi.org/10. 1016/j.energy.2008.06.002.

[4] S. Semwal, A.K. Arora, R.P. Badoni, D.K. Tuli, Biodiesel production using heterogeneous catalysts, Bioresour. Technol. 102 (2011) 2151-2161, https://doi.org/10. 1016/j.biortech.2010.10.080.

[5] A.P.S. Chouhan, A.K. Sarma, Modern heterogeneous catalysts for biodiesel production: a comprehensive review, Renew. Sustain. Energy Rev. (2011), https://doi. org/10.1016/j.rser.2011.07.112.

[6] J.S. Lee, S. Saka, Biodiesel production by heterogeneous catalysts and supercritical technologies, Bioresour. Technol. (2010), https://doi.org/10.1016/j.biortech.2010. 04.071 .

[7] J. Van Gerpen, Biodiesel processing and production, Fuel Process. Technol. (2005), https://doi.org/10.1016/j.fuproc.2004.11.005.

[8] T. Sakai, A. Kawashima, T. Koshikawa, Economic assessment of batch biodiesel production processes using homogeneous and heterogeneous alkali catalysts, Bioresour. Technol. 100 (2009) 3268-3276, https://doi.org/10.1016/j.biortech. 2009.02.010.

[9] M.K. Lam, K.T. Lee, A.R. Mohamed, Homogeneous, heterogeneous and enzymatic catalysis for transesterification of high free fatty acid oil (waste cooking oil) to biodiesel: a review, Biotechnol. Adv. 28 (2010) 500-518, https://doi.org/10.1016/ j.biotechadv.2010.03.002.

[10] T.F. Dossin, M.F. Reyniers, R.J. Berger, G.B. Marin, Simulation of heterogeneously $\mathrm{MgO}-$ catalyzed transesterification for fine-chemical and biodiesel industrial production, Appl. Catal. B Environ. (2006), https://doi.org/10.1016/j.apcatb.2006.04 008.

[11] M.Di Serio, R. Tesser, L. Pengmei, E. Santacesaria, Heterogeneous catalysts for biodiesel production, Energy Fuels 22 (2008) 207-217, https://doi.org/10.1021/ ef700250g.

[12] A. Kawashima, K. Matsubara, K. Honda, Development of heterogeneous base catalysts for biodiesel production, Bioresour. Technol. 99 (2008) 3439-3443, https:// doi.org/10.1016/j.biortech.2007.08.009.

[13] J.A. Melero, J. Iglesias, G. Morales, Heterogeneous acid catalysts for biodiesel production: current status and future challenges, Green Chem. 11 (2009) 1285-1308, https://doi.org/10.1039/B902086A.

[14] Z. Helwani, M.R. Othman, N. Aziz, J. Kim, W.J.N. Fernando, Solid heterogeneous catalysts for transesterification of triglycerides with methanol: a review, Appl. Catal. A Gen. 363 (2009) 1-10, https://doi.org/10.1016/j.apcata.2009.05.021.

[15] Y.C. Sharma, B. Singh, J. Korstad, Latest developments on application of heterogenous basic catalysts for an efficient and eco friendly synthesis of biodiesel: a review, Fuel 90 (2011) 1309-1324, https://doi.org/10.1016/j.fuel.2010.10.015.

[16] N.V. Chukanov, Heterosilicates with tetrahedral-octahedral frameworks: mineralogical and crystal-chemical aspects, Rev. Mineral. Geochem. 57 (2005) 105-143, https://doi.org/10.2138/rmg.2005.57.4

[17] J. Rocha, Z. Lin, Microporous mixed octahedral-pentahedral-tetrahedral framework silicates, Rev. Mineral. Geochem. 57 (2005) 173-201.

[18] S.M. Kuznicki, V.A. Bell, S. Nair, H.W. Hillhouse, R.M. Jacubinas, C.M. Braunbarth,
B.H. Toby, M. Tsapatsis, A titanosilicate molecular sieve with adjustable pores for size-selective adsorption of molecules, Nature 412 (2001) 720-724, https://doi. org $/ 10.1038 / 35089052$.

[19] J. Choisnet, N. Nguyen, D. Groult, B. Raveau, De nouveaux oxydes a reseau forme d'octaedres NbO6(TaO6) et de groupes Si2O7: Les phases A3Ta6Si4O26(A = Ba, $\mathrm{Sr}$ ) et K6M6Si4O26(M = Nb, Ta), Mater. Res. Bull. (1976), https://doi.org/10. 1016/0025-5408(76)90160-4.

[20] J. Choisnet, N. Nguyen, B. Raveau, Silicotantalates et siliconiobates non-stoechiometriques : Les composes K6-2xBaxTa6Si4O26( $0 \leq \mathrm{x} \leq 3)$ et K8M14Si4O47(M = Ta, Nb), Mater. Res. Bull. (1977), https://doi.org/10.1016/0025-5408(77)90093-9.

[21] E. Corcoran Jr, D.E.W. Vaughan, Hydrothermal synthesis of mixed octahedral-tetrahedral oxides: synthesis and characterization of sodium stannosilicates, Solid State Ion 32-33 (1989) 423-429, https://doi.org/10.1016/0167-2738(89)90250-6.

[22] E.W. Corcoran, D.E.W. Vaughan, P.E. Eberly, Stannosilicates and Preparation Thereof (C-2417), (1992).

[23] F.R. Abreu, D.G. Lima, E.H. Hamú, S. Einloft, J.C. Rubim, P.A.Z. Suarez, New metal catalysts for soybean oil transesterification, J. Am. Oil Chem. Soc. 80 (2003) 601-604, https://doi.org/10.1007/s11746-003-0745-6.

[24] D.A.C. Ferreira, M.R. Meneghetti, S.M.P. Meneghetti, C.R. Wolf, Methanolysis of soybean oil in the presence of tin(IV) complexes, Appl. Catal. A Gen. 317 (2007) 58-61, https://doi.org/10.1016/j.apcata.2006.10.002.

[25] T.M. Serra, D.R. de Mendonça, J.P.V. da Silva, M.R. Meneghetti, S.M. Plentz Meneghetti, Comparison of soybean oil and castor oil methanolysis in the presence of tin(IV) complexes, Fuel. 90 (2011) 2203-2206, https://doi.org/10.1016/j.fuel. 2011.02.027.

[26] W. Xie, H. Wang, H. Li, Silica-supported tin oxides as heterogeneous acid catalysts for transesterification of soybean oil with methanol, Ind. Eng. Chem. Res. 51 (2012) 225-231, https://doi.org/10.1021/ie202262t.

[27] F.R. Abreu, D.G. Lima, E. Hamú, C. Wolf, P.A. Suarez, Utilization of metal complexes as catalysts in the transesterification of Brazilian vegetable oils with different alcohols, J. Mol. Catal. A Chem. 209 (2004) 29-33, https://doi.org/10.1016/j. molcata.2003.08.003.

[28] A. Casas, M.J. Ramos, J.F. Rodríguez, Á. Pérez, Tin compounds as Lewis acid catalysts for esterification and transesterification of acid vegetable oils, Fuel Process. Technol. 106 (2013) 321-325, https://doi.org/10.1016/j.fuproc.2012.08.015.

[29] M.K. Lam, K.T. Lee, Mixed methanol-ethanol technology to produce greener biodiesel from waste cooking oil: a breakthrough for $\mathrm{SO} 42-/ \mathrm{SnO} 2-\mathrm{SiO} 2$ catalyst, Fuel Process. Technol. 92 (2011) 1639-1645, https://doi.org/10.1016/j.fuproc.2011 04.012.

[30] M.K. Lam, K.T. Lee, Accelerating transesterification reaction with biodiesel as cosolvent: a case study for solid acid sulfated tin oxide catalyst, Fuel 89 (2010) 3866-3870, https://doi.org/10.1016/j.fuel.2010.07.005.

[31] D.E. Trimbur, C.S. Im, H.F. Dillon, A.G. Day, S. Franklin, A. Coragliotti, Heterotrophic Microalgae Expressing Invertase, (2013).

[32] C. Jaeger, F. Hemmann, EASY: a simple tool for simultaneously removing background, deadtime and acoustic ringing in quantitative NMR spectroscopy-Part I: basic principle and applications, Solid State Nucl. Magn. Reson. 57-58 (2014) 22-28, https://doi.org/10.1016/j.ssnmr.2013.11.002.

[33] C. Jaeger, F. Hemmann, EASY: a csimple tool for simultaneously removing background, deadtime and acoustic ringing in quantitative NMR spectroscopy. Part II: improved ringing suppression, application to quadrupolar nuclei, cross polarisation and 2D NMR, Solid State Nucl. Magn. Reson. 63-64 (2014) 13-19, https://doi.org/ 10.1016/j.ssnmr.2014.08.001.

[34] C. Cossement, J. Darville, J. Gilles, J.B. Nagy, C. Fernandez, J. Amoureux, Chemical shift anisotropy and indirect coupling in $\mathrm{SnO} 2$ and $\mathrm{SnO}$, Magn. Reson. Chem. 30 (1992) 263-270.

[35] Q. Shu, Q. Zhang, G. Xu, Z. Nawaz, D. Wang, J. Wang, Synthesis of biodiesel from cottonseed oil and methanol using a carbon-based solid acid catalyst, Fuel Process. Technol. 90 (2009) 1002-1008, https://doi.org/10.1016/j.fuproc.2009.03.007.

[36] J. Rocha, M.W. Anderson, Microporous Titanosilicates and other Novel Mixed 
Octahedral-Tetrahedral Framework Oxides, Eur. J. Inorg. Chem. (2000), https:// doi.org/10.1002/(SICI)1099-0682(200005)2000:5 < 801::AID-EJIC801 > 3.0. CO;2-E.

[37] P.-E. Werner, L. Eriksson, M. Westdahl, TREOR, a semi-exhaustive trial-and-error powder indexing program for all symmetries, J. Appl. Crystallogr. 18 (1985) 367-370.

[38] A. Ferreira, Z. Lin, J. Rocha, C.M. Morais, M. Lopes, C. Fernandez, Ab initio structure determination of a small-pore framework sodium stannosilicate, Inorg. Chem. (2001), https://doi.org/10.1021/ic0012571.

[39] Z. Lin, A. Ferreira, J. Rocha, Synthesis and structural characterization of novel tin and titanium potassium silicates K4M2Si6O18, J. Solid State Chem. 175 (2003) 258-263, https://doi.org/10.1016/S0022-4596(03)00259-7.

[40] A. Ferreira, Z. Lin, M.R. Soares, J. Rocha, Ab initio structure determination of novel small-pore metal-silicates: knots-and-crosses structures, Inorganica Chim. Acta 356 (2003) 19-26, https://doi.org/10.1016/S0020-1693(03)00332-3.

[41] Z. Lin, J. Rocha, Synthesis and characterisation of a stannosilicate with the structure of penkvilksite-1M, Microporous Mesoporous Mater. 94 (2006) 173-178, https:// doi.org/10.1016/j.micromeso.2006.03.042.

[42] R. Millini, A. Carati, G. Bellussi, G. Cruciani, W.O. Parker, C. Rizzo, S. Zanardi, Synthesis, characterization and crystal structure of EMS-2 - a novel microporous stannosilicate, Microporous Mesoporous Mater. 101 (2007) 43-49, https://doi.org/ 10.1016/j.micromeso.2006.10.001.

[43] K.C. Song, Y. Kang, Preparation of high surface area tin oxide powders by a homogeneous precipitation method, Mater. Lett. (2000), https://doi.org/10.1016/ S0167-577X(99)00199-8

[44] E.R. Leite, I.T. Weber, E. Longo, J.A. Varela, A new method to control particle size and particle size distribution of $\mathrm{SnO} 2$ nanoparticles for gas sensor applications, Adv. Mater. (2000) 10.1002/1521-4095(200006)12:13 < 965::AIDADMA965 > 3.0.CO;2-7.

[45] K.C. Song, J.H. Kim, Synthesis of high surface area tin oxide powders via water-inoil microemulsions, Powder Technol. (2000), https://doi.org/10.1016/S00325910(99)00255-7.

[46] H.G.C.A. Fyfe, Y. Feng, H. Gondrey, G.T. Kokotailo, One-and two-dimensional highresolution solid-state NMR studies of zeolite lattice structures, Chem. Rev. 91 (1991) 1525-1543, https://doi.org/10.1021/cr00007a013.

[47] J. Klinowski, Recent advances in solid-state NMR of zeolites, Annu. Rev. Mater. Sci. 18 (1988) 189-218.

[48] M. Hunger, G. Engelhardt, H. Koller, J. Weitkamp, Characterization of sodium cations in dehydrated faujasites and zeolite EMT by 23Na DOR, 2D nutation, and MAS NMR, Solid State Nucl. Magn. Reson. 2 (1993) 111-120.

[49] M. Hunger, D. Freude, H. Pfeifer, W. Schwieger, MAS NMR studies of silanol groups in zeolites ZSM-5 synthesized with an ionic template, Chem. Phys. Lett. 167 (1990) 21-26.

[50] N. Garcia Vargas, S. Stevenson, D.F. Shantz, Synthesis and characterization of tin (IV) MFI: Sodium inhibits the synthesis of phase pure materials, Microporous Mesoporous Mater. 152 (2012) 37-49, https://doi.org/10.1016/j.micromeso.2011. 11.036.

[51] N.K. Mal, A. Bhaumik, R. Kumar, A.V. Ramaswamy, Sn-ZSM-12, a new, large pore MTW type tin-silicate molecular sieve: synthesis, characterization and catalytic properties in oxidation reactions, Catal. Letters 33 (1995) 387-394, https://doi. org/10.1007/BF00814240.

[52] Y. Chisti, Biodiesel from microalgae, Biotechnol. Adv. 25 (2007) 294-306, https:// doi.org/10.1016/j.biotechadv.2007.02.001.

[53] Y. Chisti, Biodiesel from microalgae beats bioethanol, Trends Biotechnol. 26 (2008) 126-131, https://doi.org/10.1016/j.tibtech.2007.12.002.
[54] A. Demirbas, M. Fatih Demirbas, Importance of algae oil as a source of biodiesel, Energy Convers. Manag. 52 (2011) 163-170, https://doi.org/10.1016/j.enconman 2010.06.055.

[55] T.M. Mata, A.A. Martins, N.S. Caetano, Microalgae for biodiesel production and other applications: a review, Renew. Sustain. Energy Rev. 14 (2010) 217-232, https://doi.org/10.1016/j.rser.2009.07.020.

[56] A.L. Cardoso, S.C.G. Neves, M.J. da Silva, Kinetic study of alcoholysis of the fatty acids catalyzed by tin chloride (II): an alternative catalyst for biodiesel production, Energy Fuels 23 (2009) 1718-1722.

[57] A.B. Ferreira, A.L. Cardoso, M.J. da Silva, Novel and highly efficient SnBr2-catalyzed esterification reactions of fatty acids: the notable anion ligand effect, Catal. Lett. 143 (2013) 1240-1246.

[58] M.L. Da Silva, A.P. Figueiredo, A.L. Cardoso, R. Natalino, M.J. Da Silva, Effect of water on the ethanolysis of waste cooking soybean oil using a tin (II) chloride catalyst, J. Am. Oil Chem. Soc. 88 (2011) 1431-1437.

[59] P.S. Sreeprasanth, R. Srivastava, D. Srinivas, P. Ratnasamy, Hydrophobic, solid acid catalysts for production of biofuels and lubricants, Appl. Catal. A Gen. 314 (2006) 148-159, https://doi.org/10.1016/j.apcata.2006.08.012.

[60] Z. Yang, W. Xie, Soybean oil transesterification over zinc oxide modified with alkal earth metals, Fuel Process. Technol. 88 (2007) 631-638, https://doi.org/10.1016/j. fuproc.2007.02.006

[61] D.E. López, J.G. Goodwin, D.A. Bruce, E. Lotero, Transesterification of triacetin with methanol on solid acid and base catalysts, Appl. Catal. A Gen. 295 (2005) 97-105, https://doi.org/10.1016/j.apcata.2005.07.055.

[62] M. Di Serio, R. Tesser, M. Dimiccoli, F. Cammarota, M. Nastasi, E. Santacesaria, Synthesis of biodiesel via homogeneous Lewis acid catalyst, J. Mol. Catal. A Chem. 239 (2005) 111-115, https://doi.org/10.1016/j.molcata.2005.05.041.

[63] S.P. Chavan, P.K. Zubaidha, S.W. Dantale, A. Keshavaraja, A.V. Ramaswamy, T. Ravindranathan, Use of solid superacid (sulphated SnO2) as efficient catalyst in facile transesterification of ketoesters, Tetrahedron Lett. 37 (1996) 233-236, https://doi.org/10.1016/0040-4039(95)02136-1.

[64] H. Matsuhashi, H. Miyazaki, Y. Kawamura, H. Nakamura, K. Arata, Preparation ofa solid superacid of sulfated tin oxide with acidity higher than that of sulfatedzirconia and its applications to aldol condensation and benzoylation, Chem. Mater. 13 (2001) 3038-3042, https://doi.org/10.1021/cm0104553.

[65] F. Hemmann, C. Jaeger, E. Kemnitz, Comparison of acidic site quantification methods for a series of nanoscopic aluminum hydroxide fluorides, RSC Adv. 4 (2014) 56900-56909, https://doi.org/10.1039/c4ra09477h.

[66] H.-J. Kim, B.-S. Kang, M.-J. Kim, Y.M. Park, D.-K. Kim, J.-S. Lee, K.-Y. Lee, Transesterification of vegetable oil to biodiesel using heterogeneous base catalyst, Catal. Today 93-95 (2004) 315-320, https://doi.org/10.1016/j.cattod.2004.06. 007.

[67] S.-G. Zhang, Y.-D. Wei, S.-F. Yin, S.-L. Luo, C.-T. Au, Superbasic sodium stannate as catalyst for dehydrogenation, Michael addition and transesterification reactions, Appl. Catal. A Gen. 406 (2011) 113-118, https://doi.org/10.1016/j.apcata.2011. 08.015.

[68] L.L. Marciniuk, P. Hammer, H.O. Pastore, U. Schuchardt, D. Cardoso, Sodium titanate as basic catalyst in transesterification reactions, Fuel 118 (2014) 48-54, https://doi.org/10.1016/j.fuel.2013.10.036

[69] G. Suppes, Transesterification of soybean oil with zeolite and metal catalysts, Appl Catal. A Gen. 257 (2004) 213-223, https://doi.org/10.1016/j.apcata.2003.07.010.

[70] F. Guo, Z.-G. Peng, J.-Y. Dai, Z.-L. Xiu, Calcined sodium silicate as solid base catalyst for biodiesel production, Fuel Process. Technol. 91 (2010) 322-328, https:// doi.org/10.1016/j.fuproc.2009.11.003. 